\title{
Editorial Introduction: Happenings, Acts, and Actions: Articulating the Meaning and Implications of Human Agency for Criminology by Ray Paternoster
}

\author{
Paul Mazerolle ${ }^{1}$ - Tara Renae McGee ${ }^{1}$
}

Published online: 12 December 2017

(C) Springer International Publishing AG, part of Springer Nature 2017

Earlier this year, in March, Ray Paternoster passed away after battling idiopathic pancreatitis. His family, friends, students, colleagues, and indeed the criminology community have been shocked at this unexpected loss. Ray departed this world much too soon, and while his impact on our field and the many people he touched is significant and enduring, the deep sense of loss is most profound for those who loved him and called him a friend and mentor. That represents a long list.

Ray's scholarship has been first rate, always raising questions of significance and pushing boundaries of knowledge. Ray's passion for his research and scholarship is reflected in both the academic impact of his work and its social impact. His research on crime and delinquency was always theoretically informed and empirically sophisticated. He shaped and informed theoretical and empirical understanding of crime and criminal offending across many areas. His work on deterrence, rational choice, and desistance has been at the forefront of the field for his entire career. It is hard to imagine the deficits in our understanding across so many areas without the contributions of Ray's work across his career. Ray's death penalty research was not only conceptually clear and empirically robust, its impact illustrated the discriminatory application of the death penalty in some jurisdictions in the USA. The social justice and social impact of his work in this space cannot be over-stated.

I (Paul) was privileged to study under Ray Paternoster during my $\mathrm{PhD}$ at the University of Maryland and have greatly benefited from his mentorship, his insights, his support, and friendship. Ray's mentorship skills were first rate. He knew how to nurture ideas, to guide them in directions that were consequential and he always found

Paul Mazerolle

p.mazerolle@griffith.edu.au

Tara Renae McGee

tr.mcgee@ griffith.edu.au

1 Griffith Criminology Institute, Griffith University, Brisbane, Australia 
ways to re-direct poorly thought through ideas in ways that kept students motivated and inspired. He was a mentor without peer.

Ray was deeply supportive of the JDLCC both as a reviewer, an author, and a member of the editorial board. It was clear he was supportive of the genesis behind the journal, and its emerging strength no doubt reflects the ongoing support provided by Ray and other members of this academic community. It is apposite that the most recent statistics for our journal shows that Ray's 2015 paper co-authored with Ronet Bachman and Shawn Bushway, Human Agency and the Explanation of Criminal Desistance: Arguments for a Rational Choice Theory has been the most cited paper in the JDLCC and has generated the most full text article requests across all years of the journal. Even for a new journal, Ray's impact has been huge.

Advances in thinking in criminology, indeed in any field of knowledge, are often prompted by scholars who undertake keen observations, deep reflection, consider the wider implications and challenges faced by the status quo, and work to chart new directions and conceptualizations. Ray's recent theoretical thinking has been charting such a path for criminology in respect of considering the role of human agency in understanding offending behavior and desistance.

In 2016, Ray submitted an earlier version of this paper to the journal. The review of his paper stimulated a great deal of critical discussion to which Ray responded in a revised manuscript. The main thesis of Ray's paper is that theories of human agency and theories of desistance need to be reconciled. He argues human agency is to be understood as a deliberate action. In doing so, he acknowledges the lack of conceptual clarity within existing discussions, regarding what human agency actually is and provides a critique of what he sees as "event-causality" explanations of desistance. In his paper, he challenged many of the arguments put forward by existing scholars regarding human agency and desistance; these challenges will undoubtedly continue to be debated in the years ahead. Ray's Identity Theory of Desistance has its origins in rational choice theory and has been published elsewhere. Here, he specifically discusses it in the context of human agency as deliberate action. Ultimately, Ray sees value in advancing this view of human agency as an organizing concept for the field.

As co-editors, our hope is that all new theories and ideas stimulate debate, advance dialogue, and are subjected to empirical research. Ultimately, this allows for the refinement and advancement of knowledge. To this end, we have published Ray's paper here with a response essay by Frank Cullen. In his response, Cullen puts forth five reservations including the unavoidability of positivism and its role in this issue, the situating of human agency apart from the personal traits, social contexts, and life histories of offenders, the methodological challenges required to assess human agency, the unclear value of background assumptions, and the possible negative policy implications that could flow from a human agency grounded criminology.

Cullen's responses are both salient and thought provoking and as editors we would expect nothing less from a scholar of his stature. That two esteemed criminologists, indeed giants in our field, have had an opportunity to share their insights on this topic is a rare delight for the field. It is tragic that further dialogue between them could not persist into the next issue. 
We believe that the contributions here from Ray Paternoster and Frank Cullen will inform future dialogue and research about the role of human agency in offending, and possibly advance work in the area of cognitive criminology, which as Frank Cullen observes would be a fitting tribute to the work and enduring impact of Ray Paternoster's scholarship. We wholeheartedly agree!

Paul Mazerolle

Tara Renae McGee

Co-editors 